\title{
THE NATIONAL SCHOOL LUNCH ACT: STATUTORY DIFFICULTIES AND THE NEED FOR MANDATORY GRADUAL EXPANSION OF STATE PROGRAMS
}

\section{INTRODUCTION}

The National School Lunch Act" was enacted in 1946 "to safeguard the health and well-being of the Nation's children and to encourage the domestic consumption of nutritious agricultural commodities . . . by assisting the States" in establishing school lunch programs. ${ }^{2}$ Congressional efforts to promote this policy mounted in the 1960's and 1970's with the passage of the "war on poverty" legislation of the mid-1960's ${ }^{3}$ and the Child Nutrition Act of $1966,{ }^{4}$ and with the congressional hearings on the nutritional problems of children ${ }^{5}$ culminating in the 1970 amendments to the National School Lunch Act. ${ }^{6}$

Prior to the enactment of the 1970 amendments, the Act had been interpreted as requiring only schools participating in the school lunch program to provide free or reduced price meals to eligible children. ${ }^{7}$ Shortly after the passage of the 1970 amendments, commentators ${ }^{8}$ and courts $^{9}$ viewed the amended

${ }^{1}$ The National School Lunch Act, Act of June 4, 1946, ch. 281, \$\$ 2-11, 60 Stat. 230. The Act is presently codified at 42 U.S.C. $\$ \$ 1751-63$ (1970), as amended, 42 U.S.C.A. $\$ \S 1751-68$ (Supp. 1976).

242 U.S.C. $\$ 1751$ (1970). For a general discussion of the problems of poor nutrition in this country and Congress' response to those problems, see Comment, The $\mathrm{Na}$ tional School Lunch Act and the 1970 Amendments: Renaissance or Rhetoric?, 17 Wayne L. REv. 955 (1971).

${ }^{3}$ See Annot., 14 A.L.R. Fed. 634, 636 (1973).

${ }^{4}$ Act of Oct. 11, 1966, Pub. L. No. 89-642, $\$ \$ 2-16,80$ Stat. 885 (codified at 42 U.S.C. $\$ \S 1771-85$ (1970), as amended, 42 U.S.C.A. $\$ \S 1772-87$ (Supp. 1976)).

${ }^{5}$ Hearings on S. 2152 , S. 2548, S. 2595, H.R. 515, E H.R. 11651 Before the Senate Comm. on Agriculture \& Forestry, 91st Cong., 1st Sess. (1969) [hereinafter cited as Senate Hearings]; Hearings on Nutrition \& Human Needs Before the Senate Select Comm. on Nutrition E Human Needs, 91 st Cong., 1st Sess., pt. 11 (1969) [hereinafter cited as Senate Select Comm. Hearings].

${ }^{6}$ Act of May 14, 1970, Pub. L. No. 91-248, $\$ \S 1,3-4,6-7,9,84$ Stat. 208 (codified at 42 U.S.C. $\$ \S 1751-63$ (1970), as amended, 42 U.S.C.A. $\$ \S 1751-68$ (Supp. 1976)).

${ }^{7}$ Briggs v. Kerrigan, 307 F. Supp. 295 (D. Mass. 1969), aff'd per curiam, 431 F.2d 967 (1st Cir. 1970).

${ }^{8}$ Note, The National School Lunch Program, 1970: Mandate to Feed the Children, 60 Geo. L.J. 711 (1972); Comment, supra note 2.

${ }^{9}$ E.g., Justice v. Board of Educ., 351 F. Supp. 1252 (S.D.N.Y. 1972). 
Act as requiring school districts participating in the program to provide free or reduced price lunches to all eligible children within those districts, including eligible children in schools that had not yet established school lunch programs.

This Comment examines whether the Act requires a participating school district to include within its school lunch program all eligible children within the district, or, alternatively, to make a good faith effort to expand its program to include all eligible children within the school district. A study of the relevant language of the Act, the legislative history of the 1970 amendments, and the administrative regulations implementing the Act reveals that the Act does not require a participating school district to provide free or reduced price lunches to all eligible children within the school district. Nor does the Act clearly require a school district to make a good faith effort to extend the school lunch program's coverage beyond eligible children attending participating schools within the school district.

Congress did intend, however, that the coverage of the program gradually be expanded to encompass all the children in the nation who meet the eligibility criteria, an intention that was expressed in section $1759 \mathrm{a}(\mathrm{e})(1) .{ }^{10}$ This section, however, inadequately serves the general congressional objective of the gradual expansion of the school lunch program. This Comment suggests statutory changes to effectuate that general congressional purpose. The recommended changes require participating school districts to make the good faith effort to extend the program to all eligible children within participating districts that the Act presently does not require.

\section{Present Operation of the Act}

Congress appropriates funds for the school lunch program one year before the fiscal year in which the funcis are distributed to the states. ${ }^{11}$ The appropriations are used by the Secretary of Agriculture to supply agricultural commodities and other food for the program. ${ }^{12}$ The Secretary also disburses funds to each state educational agency in an amount determined by multiplying the number of lunches served to children in schools of the state that participate in the program by a national yearly average

10 42 U.S.C.A. § 1759a(e)(1) (Supp. 1976), amending 42 U.S.C. $\$ 1759 \mathrm{a}(\mathrm{h})(1)$ (1970), reproduced at note 36 infra.

${ }^{11} 42$ U.S.C.A. $\$ 1752$ (Supp. 1976), amending 42 U.S.C. § 1752 (1970).

1242 U.S.C.A. $\$ 1753$ (Supp. 1976), amending 42 U.S.C. \$ 1753 (1970). 
payment per lunch that the Secretary deems necessary to carry out the Act's purposes. ${ }^{13}$ The national average payment may not be less than ten cents per lunch. ${ }^{14}$ States also are eligible for nonfood assistance, ${ }^{15}$ which is similarly apportioned. ${ }^{16}$

Each dollar disbursed to a state by the federal government under the Act must be matched by three dollars from sources within the state. ${ }^{17}$ Under section 1757 of the Act, ${ }^{18}$ funds received by a state for the school lunch program must then be disbursed by the state educational agency ${ }^{19}$

in accordance with such agreements approved by the Secretary as may be entered into by such State agency and the schools in the State, to those schools in the State which the State educational agency, taking into account need and attendance, determines are eligible to participate in the school-lunch program. ${ }^{20}$

The manner in which a school becomes a participant in the program permits the exercise of vast discretion on the part of local administrators of the program. To obtain federal and state funds, the School Food Authority ${ }^{21}$ (usually synonymous with "school district") must apply to the state educational agency on behalf of any school in which the Authority seeks to operate the program. ${ }^{22}$ Federal regulations require, in accordance with the express requirement of section 1757 , that schools be selected for participation in the program "on the basis of need and atten-

${ }^{13} \mathrm{Id}$.

${ }^{14}$ Id.

15 "Nonfood assistance" means equipment used by schools in storing, preparing, or serving food for school children. Id. $\$ 1760$ (d)(3), amending 42 U.S.C. $\$ 1760$ (d) (1970).

${ }^{16} 42$ U.S.C. $\$ 1754$ (1970).

1742 U.S.C.A. $\$ 1756$ (Supp. 1976), amending 42 U.S.C. $\$ 1756$ (1970). States whose per capita income is below the per capita income of the United States are required to provide a smaller amount of matching funds from sources within the state. Id.

${ }^{18}$ Id. $\$ 1757$, amending 42 U.S.C. $\$ 1757$ (1970).

19 "State educational agency" means, as the State legislature may determine, (A) the chief State school officer (such as the State superintendent of public instruction, commissioner of education, or similar officer), or (B) a board of education controlling the State department of education.

42 U.S.C. $\$ 1760(d)(2)(1970)$.

${ }^{20} 42$ U.S.C.A. $\$ 1757$ (Supp. 1976), amending 42 U.S.C. $\$ 1757$ (1970).

21 "School Food Authority" means the governing body which is responsible for the administration of one or more schools and which has the legal authority to operate a lunch program therein. The term "School Food Authority" also includes a nonprofit agency to which such governing body has delegated authority for the operation of a lunch program in a school.

7 C.F.R. \$ 210.2(p) (1976).

${ }^{22}$ Id. $\S 210.8(\mathrm{a})$. 
dance." ${ }^{23}$ The language of section 1757 has been interpreted, however, only "to impose the rather modest requirement that states make their selections with need and attendance in mind .... [S]tates are free to consider other factors which would make selection on a different basis reasonable." ${ }^{24}$ Thus, the Act does not require "that states give priority to schools whose children are generally most in need of lunches." 25 School Food Authorities for schools approved for participation in the program must enter into an agreement with the state educational agency ${ }^{26}$ wherein the School Food Authority promises, inter alia, to maintain records of its lunch program. ${ }^{27}$

Section 1758(a) of the Act delineates the "program requirements."28 Presently, this section of the law requires that "[l] unches served by schools participating in the school-lunch program" meet minimum nutritional standards set forth by the Secretary of Agriculture. ${ }^{29}$ Section 1758(b) establishes national eligibility criteria for children seeking free or reduced price lunches. ${ }^{30} \mathrm{~A}$ child who fulfills the eligibility criteria for a free

${ }^{23} I d . \S 210.8(c)(1)$.

${ }^{24}$ Ayala v. District 60 School Bd., 327 F. Supp. 980,985 (D. Colo. 1971).

${ }^{25}$ Id. at 982; Briggs v. Kerrigan, 307 F. Supp. 295, 301 (D. Mass. 1969), aff'd per curiam, 431 F.2d 967 (1st Cir. 1970).

267 C.F.R. $\S 210.8(\mathrm{e})(1976)$.

${ }^{27} I d . \S 210.8(\mathrm{e})(13)$.

2842 U.S.C.A. \$ 1758(a) (Supp. 1976), amending 42 U.S.C. § 1758 (1970).

29 The full text of this section reads:

Lunches served by schools participating in the school-lunch program under this chapter shall meet minimum nutritional requirements prescribed by the Secretary on the basis of tested nutritional research; except that such minimum nutritional requirements shall not be construed to prohibit the substitution of foods to accommodate the medical or other special dietary needs of individual students. The Secretary shall establish, in cooperation with State educational agencies, administrative procedures, which shall include local educational agency and student participation, designed to diminish waste of foods which are served by schools participating in the school lunch program under this chapter without endangering the nutritional integrity of the lunches served by such schools. Students in senior high schools which participate in the school lunch program under this chapter shall not be required to accept offered foods which they do not intend to consume, and any such failure to accept offered foods shall not affect the full charge to the student for a lunch meeting the requirements of this subsection or the amount of payments made Id. under this chapter to any such school for such a lunch.

${ }^{30} 42$ U.S.C.A. $\$ 1758(b)(1)$ (Supp. 1976), amending 42 U.S.C. $\$ 1758$ (1970) provides in part:

No later than June 1 of each fiscal year, the Secretary shall issue revised income poverty guidelines for use during the subsequent 12-month period from July through June. Such revisions shall be made by multiplying the income poverty guideline currently in effect by the change in the Consumer Price Index for the 12-month period ending in April of such fiscal year .... 
lunch must be served a free lunch under the program and a child who fulfills the eligibility criteria for a reduced price lunch must be served a lunch at a price not to exceed twenty cents. ${ }^{31}$

Section 1758 has been the subject of litigation in which plaintiffs have claimed that the section requires a school district participating in the school lunch program to provide free or reduced price lunches to all eligible children within the school district. $^{32}$ The latest decision in which section 1758 was construed, Richmond Welfare Rights Organization $v$. Snodgrass, ${ }^{33}$ rejected such an expansive reading of the section. The court held that only those schools participating in the program in a school district must provide free or reduced price lunches to eligible children. ${ }^{34}$

Section $1759 \mathrm{a}(\mathrm{e})(1)$ of the Act requires the submission of a yearly state plan by the state educational agency for the approval of the Secretary of Agriculture as a prerequisite for the receipt of federal aid under the program. ${ }^{35}$ In its plan, the state educational agency must describe the manner in which it proposes, inter alia, (1) to use the funds received under the Act to provide a free or reduced cost meal to every needy child in accordance with section 1758 , and (2) to extend the school lunch program to

Following the announcement by the Secretary of the income poverty guidelines for each 12-month period, each State educational agency shall prescribe the income guidelines, by family size, to be used by schools in the State during such 12-month period in making determinations of those eligible for a free lunch as prescribed in this section. The income guidelines for free lunches to be prescribed by each State educational agency shall not be less than the applicable family-size income levels in the income poverty guidelines prescribed by the Secretary and shall not be more than 25 per centum above such familysize income levels. Each fiscal year, each State educational agency shall also prescribe income guidelines, by family size, to be used by schools in the State during the 12-month period from July through June in making determinations of those children eligible for a lunch at a reduced price, not to exceed 20 cents. Such income guidelines for reduced-price lunches shall be prescribed at 95 per centum above the applicable family size income levels in the income poverty guidelines prescribed by the Secretary. Any child who is a member of a household, if that household has an annual income which falls between (A) the applicable family size income level of the income guidelines for free lunches prescribed by the State educational agency and (B) 95 per centum above the applicable family size income levels in the income poverty guidelines prescribed by the Secretary, shall be served a reduced price lunch at a price not to exceed 20 cents.

${ }^{31}$ Id.

${ }^{32}$ E.g., Richmond Welfare Rights Organization v. Snodgrass, 525 F.2d 197 (9th Cir. 1975); Justice v. Board of Educ., 351 F. Supp. 1252 (S.D.N.Y. 1972); Briggs v. Kerrigan, 307 F. Supp. 295 (D. Mass. 1969), aff'd per curiam, 431 F.2d 967 (Ist Cir. 1970).

${ }^{33} 525$ F.2d 197 (9th Cir. 1975).

${ }^{34} \mathrm{Id}$. at 207-08.

${ }^{35} 42$ U.S.C.A. $\S 1759 a(e)(1)$ (Supp. 1976), amending 42 U.S.C. $\S 1759 a(h)(1)$ (1970). 
all schools within the state. ${ }^{36}$ The requirement that the state educational agency describe how it proposes to extend the program to every school in the state led the Justice Department, as amicus curiae in the Snodgrass case, to contend that local school districts have a correlative duty to make a good faith effort to expand their lunch programs. ${ }^{37}$ The court rejected the contention. ${ }^{38}$

A review of the congressional amendments to the Act and their legislative history, as well as a review of certain changes in accompanying administrative regulations, is necessary to establish the framework for a consideration of the scope of the Act and the duty under the Act of participating school districts.

\section{The 1970 Amendments to the ACT}

Prior to the 1970 amendments, section 1758 of the Act provided that

[l] unches served by schools participating in the schoollunch program under this chapter shall meet minimum nutritional requirements prescribed by the Secretary. ... Such meals shall be served without cost or at a reduced cost to children who are determined by local school authorities to be unable to pay the full cost of the lunch. ${ }^{39}$

Thus, individual localities determined the eligibility criteria to be applied in the administration of the local school lunch programs. ${ }^{40}$ No maximum price for a reduced price lunch existed in the Act. ${ }^{41}$

${ }^{36}$ Section $1759 \mathrm{a}(\mathrm{e})(1)$ provides in part:

Each year by not later than a date specified by the Secretary, each State educational agency shall submit to the Secretary, for approval by him as a prerequisite to receipt of Federal funds or any commodities donated by the Secretary for use in programs under this chapter and the Child Nutrition Act of 1966, a State plan of child nutrition operations for the following school year, which shall include, as a minimum, a description of the manner in which the State educational agency proposes (A) to use the funds provided under this chapter and funds from sources within the State to furnish a free or reducedprice lunch to every needy child in accordance with the provisions of section 1758 of this title; (B) to extend the school-lunch program under this chapter to every school within the State. ...

${ }^{37}$ Brief for the United States as Amicus Curiae at 20, 21, Richmond Welfare Rights Organization v. Snodgrass, 525 F.2d 197 (9th Cir. 1975).

${ }^{38} 525$ F.2d at 207.

${ }^{39}$ Act of May 8, 1968, Pub. L. No. 90-302, $\$ 2(b), 82$ Stat. 117, amending Act of June 4, 1946, Pub. L. No. 396, § 9, 60 Stat. 233.

${ }^{40}$ This local discretion in determining the eligibility standards was an important consideration in Congress' decision to amend $\S 1758$ and establish national eligibility criteria in 1970. See authorities cited notes 48-50, 77 infra.

${ }^{41}$ Congress established such a price in 1970 . Act of May 14, 1970, Pub. L. No. 
The Department of Agriculture's regulations implementing the Act required only schools participating in the program to provide free or reduced cost lunches to eligible children. ${ }^{42}$ Thus, both the language of the statute and the language of the regulations clearly did not require participating school districts to provide free or reduced price lunches to all eligible children within those districts. In arguing that section 1758 required a participating school district to provide such lunches for all eligible children, the plaintiffs in Briggs $v$. Kerrigan ${ }^{43}$ contended that the word "schools" in section 1758 meant "school systems" or "school committees."44 In Briggs, the Boston school district served lunches under its program in only a portion of its schools. Eligible children in the remainder of Boston's schools did not receive lunches under the program. ${ }^{45}$ The court had no difficulty in rejecting the plaintiffs' interpretation and adhering to the view that a local school district need not provide free or reduced price meals for every eligible child within the district. ${ }^{46}$ Rather, the Act was satisfied when all eligible children who attended a participating school received a free or reduced price meal. ${ }^{47}$

The discretion exercised by local officials in determining which children could participate in local school lunch programs often led to arbitrary quotas that excluded children whose families had income below the poverty line. ${ }^{48}$ Standards varied from participating locality to participating locality. ${ }^{49}$ This, in turn, led to public dissatisfaction with the administration of the program. ${ }^{50}$ Congress responded to this dissatisfaction by amending the Act in $1970 .{ }^{51}$

The 1970 amendments significantly altered section 1758 . First, Congress established a ceiling of twenty cents on meals charged for those who are eligible for reduced price lunches. ${ }^{\mathbf{5 2}}$

91-248, § 6(a), 84 Stat. 210 (codified at 42 U.S.C. § 1758 (1970), as amended, 42 U.S.C.A. $\$ 1758(b)(1)$ (Supp. 1976)).

427 C.F.R. $\& 210.8(\mathrm{~d})(5)(1970)$.

${ }^{43} 307$ F. Supp. 295 (D. Mass. 1969), aff'd per curiam, 431 F.2d 967 (1st Cir. 1970).

${ }^{44} I d$. at $299,301$.

${ }^{45} I d$. at 299.

${ }^{46} I d$. at 301 .

${ }^{47} I d$.

${ }^{48}$ E.g., Shaw v. Governing Bd., 310 F. Supp. 1282 (E.D. Cal. 1970); see Note, supra note 8 , at 711-12 \& nn.5-6.

${ }^{49}$ See, e.g., Senate Hearings, supra note 5; Senate Select Comm. Hearings, supra note 5.

${ }^{50}$ E.g., Note, supra note 8 , at 712 \& n.7.

${ }^{51}$ Act of May 14, 1970, Pub. L. No. 91-248, $\S 1,3-4,6-7,9,84$ Stat. 208 (codified at 42 U.S.C. $\S \S 1751-63$ (1970), as amended, 42 U.S.C.A. \$§ 1751-68 (Supp. 1976); see Senate Hearings, supra note 5; Senate Select Comm. Hearings, supra note 5.

${ }^{52}$ Id. $\S 6(\mathrm{a}), 84$ Stat. 210 (codified at 42 U.S.C. $\S 1758$ (1970), as amended, 42 U.S.C.A. § 1758(b)(1) (Supp. 1976)). 
Second, Congress eliminated local discretion in setting minimum criteria for a child's eligibility for a free or reduced price lunch. The amendments required local school authorities to determine eligibility

in accordance with a publicly announced policy and plan applied equitably on the basis of criteria which, as a minimum, shall include the level of family income, including welfare grants, the number in the family unit, and the number of children in the family unit attending school or service institutions; but, by January 1, 1971, any child who is a member of a household which has an annual income not above the applicable family size income level set forth in the income poverty guidelines shall be served meals free or at reduced cost. ${ }^{53}$

Enumeration of the three criteria-family income, family size, and number of school children-ensured uniformity in the considerations underlying a locality's determination of eligibility. The proviso following the three criteria established income poverty guidelines ${ }^{54}$ as national minimum eligibility standards ${ }^{55}$ that local officials are bound to apply. A locality is free, however, to include more children in its program on the basis of the uniform considerations contained in the amended law. ${ }^{56}$ Third, section 1758 was amended to prevent "any overt identification of any ... child [receiving a free or reduced cost lunch] by special tokens or tickets, announced or published lists of names, or other means."57

The amendments also established in section $1759 \mathrm{a}(\mathrm{e})(1)$ the requirement that the state educational agency submit a plan to the Secretary of Agriculture, describing, inter alia, proposed efforts to expand coverage of the program, as a prerequisite for receipt of federal aid. ${ }^{58}$

${ }^{53} I d . \S 6(\mathrm{~b})$ (emphasis supplied).

${ }^{54}$ The Secretary of Agriculture was empowered to establish the poverty guidelines. Comm. of Conference, Children's Foon Service Programs, H.R. Rep. No. 91-1032, 91st Cong., 2d Sess. 9 (1970) [hereinafter cited as ConfERENCE RePORT].

${ }^{55}$ Congress has made changes in the nature of the national eligibility standards since 1970 and the law is codified presently at 42 U.S.C.A. $\$ 1758(b)(1)$ (Supp. 1976), amending 42 U.S.C. $\S 1758(1970)$. The text of $\S 1758(\mathrm{~b})(1)$ is reproduced at note 30 supra.

56 "It should be clear that, although the poverty guideline is the only mandatory national standard, children from a family meeting other criteria shall also be eligible for free or reduced-price school lunches." CONFERENCE REPORT, supra note 54, at 9.

${ }^{57}$ Act of May 14, 1970, Pub. L. No. 91-248, $\S 6($ d), 84 Stat. 210 (codified at 42 U.S.C. $\S 1758$ (1970), as amended, 42 U.S.C.A. $\$ 1758$ (b)(1) (Supp. 1976)).

${ }^{58} I d$., $\S 7,84$ Stat. 211 (codified at 42 U.S.C. $\S 1759 \mathrm{a}(\mathrm{h})(1)(1970)$, as amended, 42 


\section{IMPORT OF THE 1970 AMENDMENTS}

The 1970 changes in section 1758 of the Act have given rise to the renewed claim $^{59}$ that the section requires a school district participating in the school lunch program to provide free or reduced price meals to all eligible children within the school district. ${ }^{60}$ The addition of section $1759 \mathrm{a}(\mathrm{e})(\mathrm{l})$ has given rise to the alternate claim that the Act presently requires a participating school district to make a good faith effort to expand its school lunch program. ${ }^{61}$

\section{A. Section 1758}

In both Richmond Welfare Rights Organization v. Snodgrass ${ }^{62}$ and Justice v. Board of Education ${ }^{63}$ - cases arising after the passage of the 1970 amendments-school districts served free or reduced price meals in only a portion of their schools with the result that children meeting the national minimum eligibility standards who attended schools where free or reduced price lunches were not served could not obtain the benefit of the program. ${ }^{64}$ The plaintiffs in both cases urged that the language of amended section 1758, stating that "by January 1, 1971, any

U.S.C.A. $\S 1759 a(e)(1)$ (Supp. 1976)). The text of $\$ 1759 a(e)(1)$ is reproduced at note 36 supra.

${ }^{59}$ One case in which the same claim was raised before the 1970 amendments is Briggs v. Kerrigan, 307 F. Supp. 295 (D. Mass. 1969), aff'd per curiam, 431 F.2d 967 (1st Cir. 1970); see text accompanying notes $43-47$ supra.

${ }^{60}$ E.g., Richmond Welfare Rights Organization v. Snodgrass, 525 F.2d 197 (9th Cir. 1975); Justice v. Board of Educ., 351 F. Supp. 1252 (S.D.N.Y. 1972).

${ }_{61}$ This claim was raised by the Justice Department as amicus in Snodgrass. Brief for the United States as Amicus Curiae at 20, 21, Richmond Welfare Rights Organization v. Snodgrass, 525 F.2d 197 (9th Cir. 1975). The court in Snodgrass noted that neither of the parties to the litigation agreed with the Justice Department's claim. 525 F.2d at 207.

62525 F.2d 197 (9th Cir. 1975).

${ }^{63} 351$ F. Supp. 1252 (S.D.N.Y. 1972).

${ }^{64}$ In Snodgrass, the defendant school district had for a number of years served free and reduced price lunches under the Act in all 12 of its secondary schools. When the school district expanded the program to elementary schools, the district incorporated only six of its 49 elementary schools. Those six schools had the highest concentration of students eligible under the Act. No student attending any of the 43 remaining schools received free or reduced price lunches, although a number of those students qualified for benefits under the Act. Some of the eligible students attending the nonincorporated schools had siblings attending participating schools. The district served only one out of five of its eligible children, and denied any responsibility to serve the other four at any time. 525 F.2d at 199.

In Justice, lunches were served under the Act in only four of the 14 schools that were operated by the defendant school board. As a result, children in great need received no lunch benefits while less needy children did, schools with relatively few needy children had lunch programs while schools with up to $90 \%$ poor children did not, and siblings in eligible "families" were treated differently depending on whether they attended a participating or a nonparticipating school. $351 \mathrm{~F}$. Supp. at 1255. 
child who is a member of a household which has an annual income not above the applicable family size income level set forth in the income poverty guidelines shall be served meals free or at reduced costs," 65 requires a school district participating in the program to provide all eligible children in the district a free or reduced cost lunch. ${ }^{66}$ A review of the language of the statute, its legislative history, and the accompanying administrative regulations, however, indicates that section 1758 requires no more than that individual schools participating in the school lunch program provide free or reduced price meals to all eligible children attending those schools.

\section{Language of the Statute}

Amended section 1758 retained the opening language that existed prior to the passage of the 1970 amendments: "Lunches served by schools participating in the school-lunch program ... shall meet" certain nutritional standards. ${ }^{67}$ The sentence that followed this opening sentence in the Act prior to the passage of the 1970 amendments stated: "Such meals shall be served without cost or at a reduced cost to children who are determined by local school authorities to be unable to pay the full cost of the lunch." ${ }^{2}$ The phrase "such meals" clearly modifies "[l]unches served by schools participating in the school-lunch program." Thus, the language indicated that those children whom local authorities determined to be eligible for free or reduced price meals could receive such meals only if they attended a school pariticipating in the program. Congress amended the second sentence of section 1758 in 1970 to include a twenty-cent limitation on the price of a reduced cost lunch under the program. ${ }^{69}$ In so doing, Congress did not alter the "schools participating" language..$^{70}$

The third sentence of the amended section contains the national standards, first added to the Act in 1970, by which local

${ }^{65} 42$ U.S.C. $\S 1758$ (1970), as amended, 42 U.S.C.A. § 1758(b) (Supp. 1976) (emphasis supplied).

${ }^{66} 525$ F.2d at 202-03; 351 F. Supp. at $1257,1259$.

${ }^{67} 42$ U.S.C. $\$ 1758$ (1970), as amended, 42 U.S.C.A. § 1758(a) (Supp. 1976) (emphasis supplied).

${ }^{68}$ Act of June 4, 1946, ch. 281, § 9, 60 Stat. 233 (codified at 42 U.S.C. $\S 1758$ (1970), as amended, 42 U.S.C.A. \$ 1758(b)(1) (Supp. 1976)).

${ }^{69}$ Act of May 14, 1970, Pub. L. No. 91-248, $\$ 6($ a), 84 Stat. 210, (codified at 42 U.S.C. § 1758 (1970), as amended, 42 U.S.C.A. § 1758(b)(1) (Supp. 1976).

${ }_{70}$ The court in Justice relied nonetheless upon this amended sentence to support its holding that the amended $\S 1758$ calls for the inclusion of all eligible children in a participating school district's lunch program. 351 F. Supp. at 1259. 
school authorities must determine a child's eligibility under the Act. Not only is it logical that the opening sentence, containing the limiting phrase "participating schools," modifies the sentences that follow it, ${ }^{71}$ but the third sentence of the amended section ${ }^{72}$ speaks clearly of determinations of a child's eligibility and does not address the issue of which children actually may participate in the program. ${ }^{73}$ Moreover, other portions of section 1758 , as well as other provisions of the Act, refer to "schools,"74

${ }^{71}$ Richmond Welfare Rights Organization v. Snodgrass, 525 F.2d 197, 202-03 (9th Cir. 1975). Indeed, the amended section was codified immediately after the passage of the amendments as one lengthy paragraph. The section provided in part:

Lunches served by schools participating in the school-lunch program under this chapter shall meet minimum nutritional requirements prescribed by the Secretary on the basis of tested nutritional research; except that such minimum nutritional requirements shall not be construed to prohibit the substitution of foods to accommodate the medical or other special dietary needs of individual students. Such meals shall be served without cost or at a reduced cost not exceeding 20 cents per meal to children who are determined by local school authorities to be unable to pay the full cost of the lunch. Such determinations shall be made by local school authorities in accordance with a publicly announced policy and plan applied equitably on the basis of criteria which, as a minimum, shall include the level of family income, including welfare grants, the number in the family unit, and the number of children in the family unit attending school or service institutions; but, by January 1, 1971, any child who is a member of a household which has an annual income not above the applicable family size income level set forth in the income poverty guidelines shall be served meals free or at reduced cost.

42 U.S.C. $\$ 1758$ (1970), as amended, 42 U.S.C.A. $\$ 1758$ (Supp. 1976). It was not until 1972 that separate subsections were designated in $\$ 1758$ as the section underwent changes with regard to the nature of the national eligibility standards. Act of Sept. 26, 1972, Pub. L. No. 92-433, § 5, 86 Stat. 726, amending 42 U.S.C. $\S 1758$ (1970). The "schools participating" language appeared in subsection (a) and the eligibility criteria appeared in subsection (b). Section 1758 is codified presently in substantially the same form at 42 U.S.C.A. $\$ 1758$ (Supp. 1976).

${ }^{72}$ Text accompanying note 53 supra.

${ }^{73}$ See Richmond Welfare Rights Organization v. Snodgrass, 525 F.2d 197, 202-03

(9th Cir. 1975).

${ }^{74}$ Section 1758(a) provides in part:

The Secretary shall establish, in cooperation with State educational agencies, administrative procedures, which shall include local educational agency and student participation, designed to diminish waste of foods which are served by schools participating in the school lunch program under this chapter without endangering the nutritional integrity of the lunches served by such schools.

42 U.S.C.A. § 1758(a) (Supp. 1976), amending 42 U.S.C. \$ 1758 (1970) (emphasis supplied). This provision was added in 1975. Act of Oct. 7, 1975, Pub. L. No. 94-105, $\S 6(a), 89$ Stat. 512.

Section 1758(c) provides in part:

Each school shall, insofar as practicable, utilize in its lunch program commodities designated from time to time by the Secretary as being in abundance, either nationally or in the school area, or commodities donated by the Secretary. Commodities purchased under the authority of section $612 \mathrm{c}$ of Title 7, may be donated by the Secretary to schools, in accordance with the needs as determined by local school authorities, for utilization in the school-lunch program under this chapter as well as to other schools carrying out nonprofit 
indicating that the Act operates on the premise that the school, rather than the school district, is the appropriate unit of participation in the program.

The language of the statute, then, supports the contention that only schools participating in the school lunch program must serve free or reduced price lunches to all eligible children.

\section{Legislative History}

The legislative history of the 1970 amendments contains sweeping generalizations made by some legislators, ${ }^{75}$ sometimes without reference to the language added to section $1758,{ }^{76}$ that suggest that the amendments gave all eligible children a right to a free or reduced price lunch. These statements create some ambiguity in the legislative record concerning the congressional intent behind the section 1758 amendments, but the legislative

school-lunch programs and institutions authorized to receive such commodities. The Secretary is authorized to prescribe terms and conditions respecting the use of commodities donated under such section $612 \mathrm{c}$ of Title 7 , under section 1431 of Title 7, and under section $1446 \mathrm{a}-1$ of Title 7 , as will maximize the nutritional and financial contributions of such donated commodities in such schools and institutions. The requirements of this section relating to the service of meals without cost or at a reduced cost shall apply to the lunch program of any school utilizing commodities donated under any of the provisions of law referred to in the preceding sentence.

42 U.S.C.A. \$ 1758(c) (Supp. 1976), amending 42 U.S.C. § 1758 (1970) (emphasis supplied).

Section 1753 provides in part:

For each fiscal year the Secretary shall make food assistance payments, at such times as he may determine, from the sums appropriated therefor, to each State educational agency, in a total amount equal to the result obtained by multiplying the number of lunches (consisting of a combination of foods which meet the nutritional requirements prescribed by the Secretary under section 1758(a) of this title) served during such fiscal year to children in schools in such State, which participate in the school lunch program under this chapter under agreements with such State educational agency, by a national average payment per lunch for such fiscal year determined by the Secretary to be necessary to carry out the purposes of this chapter....

42 U.S.C.A. \& 1753 (Supp. 1976), amending 42 U.S.C. $\S 1753$ (1970) (emphasis supplied).

Section 1755(a) provides in part:

[Funds appropriate to carry out the Act and the Child Nutrition Act of 1966] shall be available to the Secretary during such year for direct expenditure by him for agricultural commodities and other foods to be distributed among the States and schools and service institutions participating in the food service programs under this chapter and under the Child Nutrition Act of 1966 in accordance with the needs as determined by the local school and service institution authorities.

42 U.S.C.A. § 1755(a) (Supp. 1976), amending 42 U.S.C. $\$ 1755$ (1970) (emphasis supplied).

${ }^{75}$ Text accompanying notes $82-84$ infra.

${ }^{76}$ See text accompanying note 86 infra. 
record on the whole indicates that the generalizations of these legislators do not represent Congress' intent in enacting the 1970 amendments.

The amendments to section 1758 were designed to limit local discretion by (1) establishing national standards for determining a child's eligibility under the Act, ${ }^{77}$ and (2) placing a ceiling on the price of a reduced price lunch. ${ }^{78}$ Congress also sought to prevent the singling out of children participating in the program as an identifiable class. ${ }^{79}$

The original Senate bill contained a two-tiered national eligibility standard:

[B]ut any child who is a member of a household which (1) is eligible to participate in a Federal food stamp program or commodity distribution program or (2) has an annual income equivalent to $\$ 4000$ or less for a household of four persons shall be served meals without cost. $^{80}$

The Senate-House Conference Committee, resolving differences between the House and Senate versions of the amendments, replaced the two-tiered standard with the single-level criteria of the income poverty guidelines, which was agreed to by both houses of Congress. ${ }^{81}$

Statements by some legislators, however, indicate that the establishment of national eligibility criteria mandated the participation of all eligible children in the program. For example, the Conference Committee Report contained the following statement by the House conferees: "[T] reduced price lunches makes it clear that every child from a household with an income below the poverty level shall be served free or reduced price meals." 82 Senator McGovern stated that "the language . . . that every needy child 'shall be served meals' ... creates ... 'a right to a school lunch.' This is a right bestowed on the children of America." 83 Senator Javits claimed: "The law

${ }^{77}$ E.g., Senate Hearings, supra note 5, at 176 (statement of Senator McGovern); id. 245-47 (statement of John R. Kramer); 116 Cong. Rec. 13606 (1970) (remarks of Senator McGovern); id. 13607 (remarks of Senator Javits).

${ }^{78}$ E.g., 116 CoNG. Rec. 13607 (1970) (remarks of Senator Javits). The purpose of this limitation was also "to bring meals to children who could not afford the meal at the regular price." Id.

${ }^{79}$ Id. 13608 (remarks of Senator Dole).

so Id. 4492.

${ }^{81}$ The final version of the eligibility provision is reproduced at text accompanying note 53 supra.

${ }^{82}$ Conference Report, supra note 54 , at 9.

83 116 Cong. REC. 13606 (1970) (remarks of Senator McGovern). 
will be clear: any child at poverty level must receive a free or reduced price lunch .... This makes crystal clear that poor children can no longer be denied free or reduced cost lunches." 84

The language of the statute, however, does not support such an expansive reading of the amendments to section $1758 .^{85} \mathrm{In}-$ deed, some of the expansive rhetoric asserting that all eligible children must be fed under the program may have been directed to the amendment that requires a state to submit plans proposing the expansion of the school lunch program to every school in the state. ${ }^{86}$

Representative Quie, a manager of the bill in the House of Representatives and a member of the Conference Committee, put the section 1758 amendment that established a national eligibility standard in its proper perspective in response to the expansive reading given the amendment by some Congressmen:

I think it is important to clarify some misunderstandings that may exist in regard to changes that were made in the conference report. As you know, several amendments to the original bill were made on the floor of the Senate. House conferees felt that some modifications to those amendments were necessary. Much attention has been focused specifically on the new eligibility language in section [1758] which states:

Free lunches shall be served to low-income children or children being eligible for school lunches.

${ }^{84}$ Id. 13607 (remarks of Senator Javits). Even the seemingly unequivocal statements in text accompanying notes 82-84 supra are made without reference to the "schools participating" language that was retained at the beginning of $\S 1758$. See text accompanying notes 67-74 supra. It is impossible to determine whether the legislators who made these remarks assumed that the "schools participating" language governed the scope of participation in the program and therefore intended the sweeping claims that "every eligible child shall be served free or reduced price meals" to be confined to "schools participating in the school-lunch program."

Indeed, if the claims of these legislators were taken at face value, without reference to the limits on participation, the amendment's effect would be to require that all eligible children, in both participating and nonparticipating school districts, be fed under the program. Yet the program is a voluntary one at both the state and local levels. Richmond Welfare Rights Organization v. Snodgrass, 525 F.2d 197, 205 (9th Cir. 1975); Justice v. Board of Educ., 351 F. Supp. 1252, 1254 (S.D.N.Y. 1972); Shaw v. Governing Bd., 310 F. Supp. 1282, 1286 (E.D. Cal. 1970). Had Congress intended such a vast expansion of the program, Congress would have provided explicitly for such an expansion in the statute's language. Similarly, had Congress intended a lesser, but still significant extension of the program to all schools within a participating school district, Congress probably would have deleted the "schools participating" language and provided explicitly for the extension.

${ }_{85}$ Text accompanying notes $67-74$ suipra.

${ }^{86} 42$ U.S.C.A. § $1759 \mathrm{a}(\mathrm{e})(1)$ (Supp. 1976), amending 42 U.S.C. $\$ 1758 \mathrm{a}(\mathrm{h})(1)(1970)$. 
The wording in my judgment is academic because the existing School Lunch Act, in section [1758], ... now reads:

Such meals shall be served without cost or at a reduced cost to children who are determined by local school authorities to be unable to pay the full cost of the lunch.

Mr. Speaker, our action in conference takes the basic concept already in the law and expands it so that all poor children shall be served free or reduced-price meals on a standard as determined by the Secretary of Agriculture. The discretion for determination as presently written in the law remains with the local school authority. ${ }^{87}$

Thus, according to Representative Quie, the eligibility amendment to section 1758 was intended to deprive local school authorities of the discretion to set minimum eligibility standards for the program, rather than to change the unit of participation from schools to school districts. Representative Quie pointed out in effect that the second sentence of section 1758 already established which eligible children actually may participate in the program: those eligible children who are attending schools participating in the program..$^{88}$

Representative Quie also addressed the meaning of the phrase "shall be served" in the amendment:

Another change as noted in the newspapers, I feel there has been a misrepresentation of what we attempted to do on the House side in the conference report. When the Members of the other body suggested that we continue to use those words, "shall be served," instead of "shall be eligible," we accepted that change because we understood the meaning was the same anyway and while it made the language redundant, it made the amendment absolutely clear. ${ }^{89}$

Thus, insertion of the phrase "shall be served" in lieu of the phrase "shall be eligible" in the national eligibility standard" was not intended to change the unit of participation in the Act; the amendment's purpose was merely to establish minimum national eligibility criteria. Indeed, in discussing the original amendment

${ }^{87} 116$ CoNG. ReC. 13993-94 (1970) (remarks of Representative Quie) (emphasis supplied).

${ }^{88}$ This argument is articulated more fully in text accompanying notes 67-74 supra.

89116 CoNG. REC. 13994 (1970) (remarks of Representative Quie).

9042 U.S.C. $\S 1758$ (1970), as amended, 42 U.S.C.A. $\$ 1758(b)(1)$ (Supp. 1976). 
to the Senate bill that established the two-tiered national eligibility standard, Senator McGovern referred to the amendment as establishing

uniform, nationwide eligibility standards. . . .

All pupils from households eligible to receive food stamps or commodities or from families of four with an annual income of $\$ 4,000$ or less, the same standard we used on the food stamp program-or the equivalent for households of other sizes-would be eligible. These are the children who would be eligible for free school lunches. The amendment would apply to schools which receive cash or commodity support of their school lunch program. ${ }^{91}$

Moreover, an amendment sponsored by Senator McGovern that would have had the effect of requiring a participating school district to provide free or reduced price lunches to all eligible school children within the district was rejected by the Senate Committee on Agriculture and Forestry. ${ }^{92}$ The amendment would have substituted the phrase "local educational agencies" (i.e., school districts) for the word "schools" in the critical first sentence of section $1758 .{ }^{93}$ The first sentence of section 1758 would then have read: "Lunches served by local educational agencies shall meet minimum nutritional requirements ...." Thus, the mandatory requirement that all eligible children be served meals - with eligibility determined either by "local school authorities" as provided in the original Act, ${ }^{\mathbf{9 4}}$ or by the application of the national eligibility criteria subsequently adopted by Congress in $1970^{95}$-would be imposed on the participating school districts rather than the participating schools. The avowed purposes of the amendment were: (1) to increase the school lunch program's administrative efficiency by permitting school districts rather than individual schools to be the contracting agency in the program, thus enhancing, for example,

91116 CoNG. Rec. 4403 (1970) (remarks of Senator McGovern).

92 Senate Comm. on Agriculture and Forestry, Report on School Lunch and Child Nutrition Amendments, S. Rep. No. 91-641, 91st Cong., 2d Sess. 3-4 (1970) [hereinafter cited as SeNate RePORT].

${ }^{93} I d$. 25. The amendment also would have substituted "local educational agencies" for the word "schools" in other portions of the Act. Id.

${ }^{94}$ Act of June 4, 1946, ch. 281, $\$ 9,60$ Stat. 233, as amended, Act of May 8, 1968, Pub. L. No. 90-302, $\$$ 2(b), 82 Stat. 117, reproduced at text accompanying note 39 supra.

9542 U.S.C. $\S 1758$ (1970), as amended, 42 U.S.C.A. $\$ 1758($ b)(1) (Supp. 1976). 
economies of purchasing scale, ${ }^{96}$ and (2) to ensure some uniformity in eligibility criteria. ${ }^{97}$ Although the legislative record does not reveal any discussion of the proposed amendment's impact on the unit of participation in the program, the expansive impact of the amendment is apparent when section 1758 is read with the amended language. ${ }^{98}$ Indeed, there is some indication that proponents of the amendment, ${ }^{99}$ as well as the Senate Committee on Agriculture and Forestry, ${ }^{100}$ were aware of the broad effect of the amendment, even while they discussed its aims in other terms. ${ }^{101}$

Thus, the floor debate and the defeat of the McGovern amendment support the view that by enacting the 1970 amendments Congress did not intend to expand mandatory coverage of the program to all eligible children in a participating school district.

\section{Administrative Regulations}

Administrative interpretation of the Act carries some weight but is not dispositive in a court's determination of the meaning of the Act. ${ }^{102}$ The administrative regulations adopted by the Department of Agriculture to implement the 1970 amendments contain ambiguities and consequently have been interpreted inconsistently by reviewing courts. ${ }^{103}$

Following the enactment of the 1970 amendments, a new set of regulations entitled "Determining Eligibility for Free and Reduced Price Lunches," was established to implement the 1970 amendments. ${ }^{104}$ Section 245.1, the "general purpose and scope" section of the new regulations, provided:

Section [1758] of the National School Lunch Act, as amended, requires that schools participating in the na-

${ }^{96}$ Senate RePort, supra note 92, at 3, 27; Senate Hearings, supra note 5, at 176 (statement of Senator McGovern); id. 248-49 (statement of John R. Kramer).

${ }^{97}$ Senate RePort, supra note 92, at 27.

${ }^{98}$ See text accompanying notes 93-95 supra.

${ }^{99}$ See Senate RePORT, supra note 92, at 27; Senate Hearings, supra note 5, at 249 (statement of John R. Kramer).

${ }^{100}$ See Senate RePort, supra note 92, at 4.

101 Text accompanying notes 96-97 supra.

${ }_{102}$ Davis v. Robinson, 346 F. Supp. 847, 856 (D.R.I. 1972).

${ }^{103}$ See, e.g., Richmond Welfare Rights Organization v. Snodgrass, 525 F.2d 197, 204-05 (9th Cir. 1975); Justice v. Board of Educ., 351 F. Supp. 1252, 1260-61 (S.D.N.Y. 1972).

10435 Fed. Reg. 14065 (1970). The old regulations, in which responsibility for determining eligibility standards was delegated to localities pursuant to the preamended Act, are at 33 Fed. Reg. 15674 (1968). 
tional school lunch program . . . shall (a) serve lunches free or at a reduced price to children who are determined by local school authorities to be unable to pay the full price of the lunches [according to specified minimum criteria]. . . . ${ }^{105}$

Thus, the introductory language of the regulations reflects a limitation of the program to participating schools.

Section 245.3, the section on "eligibility standards for free and reduced price lunches," however, contained broader language:

Each school food authority ${ }^{106}$ shall serve lunches free or at a reduced price to all children whom it determines, in accordance with the requirements of this part, are unable to pay the full price of the lunch. . . . [Eligibility] standards shall specify the specific criteria to be used, respectively, for free lunches and for reduced price lunches; they shall be applicable to all schools under the jurisdiction of the school food authority; and they shall provide that all children from a family meeting the eligibility standards and attending any school under the jurisdiction of the school food authority shall be provided the same benefits. ${ }^{107}$

Moreover, section 245.6 said:

If a child transfers from one school to another school under the jurisdiction of the same school-food authority, his eligibility for a free or reduced-price lunch, if previously established, shall be transferred to, and honored by, the receiving school. ${ }^{108}$

The court in Justice, relying in part upon the latter two sections of the regulations, interpreted the administrative regulations as providing for the inclusion in the school lunch program of all eligible school children in a participating school district. ${ }^{109}$ The Snodgrass court, however, emphasized the limitation to "participating schools" in the "general purpose and scope" section and found that the regulations did not require mandatory par-

1057 C.F.R. $\$ 245.1$ (1971) (emphasis supplied).

106 "School food authority" was defined in the regulations as the governing body administering one or more schools (i.e., a school district). Id. § 210.2(p) (1971). The current definition of "school food authority" is the same. Id. § 210.2(p) (1976).

${ }^{107}$ Id. \$ 245.3(a) (1971) (emphasis supplied).

${ }^{108} I d . \S 245.6(\mathrm{~b})$.

${ }^{109} 351$ F. Supp. at 1260-61. 
ticipation by all schools within a participating school district. ${ }^{110}$ Indeed, the limitation to "participating schools" at the outset of the regulations, a limitation unchanged during all subsequent alterations of section $245,{ }^{111}$ parallels the limitation in the statutory scheme itself. ${ }^{12}$ Section 245.1 , as the general purpose and scope section of the regulations, logically governs the scope of participation for children meeting the eligibility criteria that follow in section 245.3.113

Moreover, the regulations have been changed since 1970 to reflect more clearly the limitation of the program to participating schools. Section 245.3 has been modified to limit coverage of eligible children expressly to schools participating in the program. ${ }^{114}$ Furthermore, the requirement that a transfer student's eligibility be honored by the receiving school has been limited to those receiving schools that participate in the program. ${ }^{115}$ Apparently, the Department of Agriculture has consistently interpreted the regulations as applying only to schools participating in the program. ${ }^{116}$ The modifications in the regulations

110525 F.2d at 204-05.

11 See, e.g., 40 Fed. Reg. 57206 (1975); 39 Fed. Reg. 30337 (1974); 38 Fed. Reg. 14953-54 (1973); 37 Fed. Reg. 23323 (1972); 36 Fed. Reg. 21870 (1971). In 1973, for example, the Department of Agriculture revised $\$ 245.1$ because it deemed the section unclear. 38 Fed. Reg. 14954 (1973). The "schools participating" language was retained. Id. 14957.

${ }^{112}$ See text accompanying notes 67-74 supra.

113 The regulations restate the criteria of $\S 1758$ as the section was amended in 1970. 7 C.F.R. \& 245.3(b) (1971).

${ }^{114} I d . \$ 245.3(\mathrm{~b})$ (1976) provides in part:

Each School Food Authority shall establish eligibility criteria for free and reduced price meals and for free milk in conformity with the family-size income standards prescribed by the State agency, or FNSRO where applicable, under paragraph (a) of this section. Such criteria shall: (1) Specify the uniform family-size income criteria to be used for determining eligibility for free and reduced price meals and for free milk in all schools participating in the National School Lunch Program, School Breakfast Program, or Special Milk Program and in commodity only schools under the jurisdiction of the School Food Authority; and (2) provide that all children from a family meeting family-size income criteria and attending any school under the jurisdiction of the School Food Authority which participates under the National School Lunch Program, School Breakfast Program, Special Milk Program, or is a commodity only school shall be provided the same benefits.

Id. (emphasis supplied).

1157 C.F.R. $\$ 245.3(\mathrm{c})$ (1976) provides in part:

If a child transfers from one school to another school under the jurisdiction of the same School Food Authority, his eligibility for free or reduced price meals or for free milk, if previously established, shall be transferred to, and honored by, the receiving school, if it participates in the National School Lunch Program, School Breakfast Program, Special Milk Program, or is a commodity only school.

Id. (emphasis supplied).

${ }^{116}$ Brief for the United States as Amicus Curiae at 16-19, Richmond Welfare 
to limit coverage expressly to eligible children within participating schools seem to represent a clarification of the meaning of the regulations rather than a substantive shift in the Department of Agriculture's interpretation of the appropriate unit of participation in the program. ${ }^{117}$ The administrative regulations, then, do not support the contention that the 1970 amendments were aimed at expanding the scope of mandatory participation to all schools in participating school districts.

Thus, a review of the language of the statute, the legislative history of the 1970 amendments, and the administrative regulations implementing the 1970 amendments supports the view that only eligible children in schools participating in the program must be fed under the program.

It should be noted that the success of a litigant's claim that section 1758 requires a participating school district to feed all eligible children could have a serious practical impact adverse to the litigant's interests and the goals of the Act. The school district, faced with the increased burden of financing additional eligible school children, may withdraw from the program. Indeed, several school districts faced with the prospect of an adverse judgment in such litigation withdrew from participation in the school lunch program ${ }^{118}$ or threatened to withdraw. ${ }^{119} \mathrm{Ab}$ sent the denial by a school district of an affected party's constitutional rights, such a withdrawal is permissible. ${ }^{120}$ Thus, a success-

Rights Organization v. Snodgrass, 525 F.2d 197 (9th Cir. 1975). The changes in the administrative regulations that expressly limited coverage of eligible children to children who are attending schools participating in the program and the consistent administrative interpretation of the regulations as so limiting the program's coverage were among the factors that persuaded the Snodgrass court that the Justice court's reliance on the earlier regulations was misplaced. 525 F.2d at 205 . The Snodgrass court also relied upon $\S 245.1$ of the regulations. Id. at 204-05.

${ }^{117}$ See Richmond Welfare Rights Organization v. Snodgrass, 525 F.2d 197, 205 (9th Cir. 1975). In 1973, the Department of Agriculture, in commenting upon a revision of its regulations, identified its interpretation of Congress' intent in passing the 1970 amendments: "The Department believes . . . that the intent of section 9 of the National School Lunch Act, as amended . . . was to establish nationwide uniformity in lieu of local discretion . . . "38 Fed. Reg. 14954 (1973). The Department of Agriculture's interpretation of Congress' intent, consistent with the Department's administration of the program, note 101 supra \& accompanying text, did not acknowledge an alteration in the unit of participation.

${ }^{118}$ E.g., Richmond Welfare Rights Organization v. Snodgrass, 525 F.2d 197, 200 (9th Cir. 1975).

${ }^{119}$ Justice v. Board of Educ., 351 F. Supp. 1252, 1264 n.30 (S.D.N.Y. 1972); Jones v. Board of Educ., 348 F. Supp. 1269, 1270 (N.D. Ohio 1972), rev'd on other grounds, 474 F.2d 1232 (6th Cir. 1973).

${ }^{120}$ Richmond Welfare Rights Organization v. Snodgrass, 525 F.2d 197, 205-06 (9th Cir. 1975); see Justice v. Board of Educ., 351 F. Supp. 1252, 1264 n.30 (S.D.N.Y. 1972); Shaw v. Governing Bd., 310 F. Supp. 1282, 1286 (E.D. Cal. 1970). 
ful claim that section 1758 requires a participating school district to feed all eligible children within the district could lead to the termination of program benefits for every eligible child within the school district. Such a result thwarts the congressional purpose of gradually expanding the school lunch program to include every needy child in the nation. ${ }^{121}$

\section{B. Section $1759 a(e)(1)$}

The 1970 amendments also established a section of the Act, presently section $1759 \mathrm{a}(\mathrm{e})(1)$, that requires the state educational agency to submit a yearly plan for the approval of the Secretary of Agriculture as a prerequisite of the receipt of federal aid under the Act. The state educational agency must describe in this plan the manner in which it proposes, inter alia, (1) to use funds received under the Act to provide a free or reduced price meal to all eligible children in accordance with section 1758 , and (2) to extend the school lunch program to all schools within the state. ${ }^{122}$ The state educational agency is required, in effect, to describe the manner in which it intends to encourage nonparticipating school districts and nonparticipating schools within participating school districts to join the program. ${ }^{123}$

The purpose of section $1759 \mathrm{a}(\mathrm{e})(1)$ is to ensure the gradual extension of coverage of the school lunch program to every child in the nation who meets the program's national eligibility criteria. ${ }^{124}$ The Justice Department, as amicus, urged upon the court in Snodgrass the view that section 1759 a(e)(1) imposes a correlative duty on the part of participating school districts to

121 See note 124 infra.

12242 U.S.C.A. \$ $1759 \mathrm{a}(\mathrm{e})(1)$ (Supp. 1976), amending 42 U.S.C. $\S 1758 \mathrm{a}(\mathrm{h})(1)$ (1970).

${ }^{123}$ See Brief for the United States as Amicus Curiae at 15, Richmond Welfare Rights Organization v. Snodgrass, 525 F.2d 197 (9th Cir. 1975).

${ }^{124}$ Senator Talmadge said, for example: "The pending bill places a positive mandate on each State to extend the school lunch program to every school in the state and to provide a free lunch or reduced price meal to every needy child in the state." 116 Cong. Rec. 13603 (1970) (remarks of Senator Talmadge); see, e.g., id. 4407-08 (remarks of Senator McGovern); id. 13606 (remarks of Seriator Spong); id. 13994 (remarks of Representative Quie).

The Senate bill required initially that states plan to include every school in the national school lunch program by the start of the 1972-1973 school year. ConferevcE REPORT, supra note 54, at 10; 116 CoNg. REC. 4407 (1970). The Conference Committee deleted the 1972-73 deadline. Conference Report, supra note 54, at 10. This change made the congressional purpose clear: the school lunch program was to undergo gradual expansion and a state educational agency's failure to include all schools within the program by any particular year need not constitute noncompliance with the statutory mandate. 116 CoNG. REc. 13604 (1970) (remarks of Senator Talmadge). 
propose and implement local expansion programs. ${ }^{125}$ The court found no support for such a duty in the statutory scheme. ${ }^{126}$ The lack of a correlative duty on the part of participating school districts frustrates the realization of the purpose of section $1759 \mathrm{a}(\mathrm{e})(1)$. Without such a duty, the program's gradual expansion rests solely upon the attempts of state educational agencies to prod nonparticipating school districts into joining the program and to prompt participating school districts into extending the coverage of their programs to more schools and more eligible children within the districts.

In order to effectuate better the congressional purpose of gradually extending the school lunch program to all schools and all eligible children in a state, this Comment proposes an amendment to the Act that places a requirement on participating school districts to make a good faith effort to extend the coverage of the program gradually to all schools and eligible children within those districts. ${ }^{127}$ The amendment requires a state educa-

${ }^{125}$ Brief for the United States as Amicus Curiae at 15, 20-21, Richmond Welfare Rights Organization v. Snodgrass, 525 F.2d 197 (9th Cir. 1975).

${ }^{126} 525 \mathrm{~F} .2 \mathrm{~d}$ at 207 . The Snodgrass court is correct in its conclusion that no affirmative support exists in the Act for a duty on the part of participating school districts to undertake expansion of their school lunch programs. But a letter (adduced by the Justice Department in its amicus brief in Snodgrass, Brief for the United States as Amicus Curiae at app. A, Richmond Welfare Rights Organization v. Snodgrass, 525 F.2d 197 (9th Cir. 1975)) from a Department of Agriculture official to a state education department attorney suggests that the Department may interpret the Act to impose such a duty:

Thus, while the legislation does not direct immediate implementation everywhere, the Act, as amended in 1970, does contemplate full participation in all districts as an ultimate goal to be achieved as rapidly as State and Federal resources can be effectively utilized and no school district will be permitted to establish partial implementation as a permanent pattern.

Letter from John A. Harris, Acting Director of the Commodity Stabilization Division of the Office of General Counsel, Department of Agriculture, to Lawrence W. Reich, Associate Attorney of the State Education Department of New York, Mar. 5, 1973, at 2. The language quoted from the letter is ambiguous, however, and no clear support for a duty on the part of participating school districts to implement expansion programs is found in the Department of Agriculture's regulations.

${ }^{127}$ One manner in which the program could be expanded to cover all schools and eligible children within a state is by resort to state law. The Illinois and Rhode Island laws implementing the school lunch programs in those states require all public schools to maintain school lunch programs. Ill. REv. STAT. ch. 122, \& 712.4 (Supp. 1976); R.I. GEN. LAwS ANN: $§ 16-8-10$ (Supp. 1975). While the Snodgrass litigation was in progress, the California legislature passed an Act, ch. 1277, \& 10, [1975] Cal. Stats. _ (codified at Cal. Educ. Code $\S \S 11930-36$ (West Supp. 1976)), providing that "each school district and county superintendent of schools maintaining any kindergarten or any of grades I to 12 shall ... provide for each needy pupil ... one nutritionally adequate free or reduced-price meal during each schoolday." CaL. EDuc. CoDE $\S 11930$ (West Supp. 1976).

An advantage of reliance on state law is the elimination of a school district's option to withdraw from the program. See text accompanying notes 118-21 supra. The passage 
tional agency to assist participating school districts in making their good faith efforts to expand the program and directs that the state educational agency itself make a good faith effort to extend the program to all eligible children within the state.

\section{Proposed Statutory Amendment}

An amendment that imposes a duty upon participating school districts to make a good faith effort gradually to expand the coverage of the school lunch program acknowledges the fiscal difficulties inherent in a commitment to fulfill immediately the goal of feeding every eligible child under the Act. ${ }^{128}$ The requirement of a good faith effort gradually to expand the school lunch program permits participating school districts to undertake an orderly expansion of the program consistent with the financial resources at their disposal. State educational agencies remain solely responsible for extending the program's coverage to nonparticipating school districts in the state. ${ }^{129}$ The following amendment is offered as an improved means of implementing the congressional goal of gradual inclusion in the school lunch program of all eligible children in the nation:

$\$ 1758$ a. Submission of school food authority and State educational agency plans on gradual expansion to all schools under their jurisdiction -State review.

For the purpose of ensuring the gradual extension of the coverage of the National School Lunch Act to all eligible children in the nation, as defined by section 1758, the school food authority and the State educational agency are required to submit plans in accordance with sections $1758 \mathrm{a}(\mathrm{a})(1)$ and $1758 \mathrm{a}(\mathrm{b})(2)$.

(a)(1) Each year, by not later than a date specified by the Secretary, each school food authority participating in the school lunch Program shall submit a plan to the State educational agency specifying the manner in

of such mandatory participation laws in all states, however, is an unlikely occurrence because of the increased expenditures within individual states that would result from the implementation of the requirement. In any event, the hurried implementation of such a mandatory participation requirement, as well as the sudden imposition of possibly drastic expenditure increases on localities, is undesirable.

${ }^{128}$ Local school districts, faced with the burden of implementing a requirement of immediate, full participation, might opt to withdraw entirely from the program. Notes 118-21 supra \& accompanying text.

129 Text accompanying note 123 supra. 
which the school food authority proposes (A) to expand the Program to include every needy child under its jurisdiction in accordance with section 1758 , and (B) to extend the Program to all schools under its jurisdiction.

(2) The school food authority must make a good faith effort to fulfill the proposals contained in the plan submitted under section $1758 \mathrm{a}(\mathrm{a})(1)$.

(b)(1) The State educational agency shall assist each school food authority participating in the Program in making its good faith effort to comply with the plan it submits under section $1758 \mathrm{a}(\mathrm{a})(1)$.

(2) [Formerly contained in section $1759 \mathrm{a}(\mathrm{e})(1)]$ Each State educational agency shall submit to the Secretary a State plan of child nutrition operation for the following school year that shall include a description of the manner in which the State educational agency proposes (A) to use the funds allocated to the Program to furnish free or reduced price lunches to every needy child; (B) to extend the Program to every school within the State; and (C) to use the funds to the maximum extent practicable to reach needy children. The State plan shall also include (D) the plans of each school food authority submitted under section $1758 \mathrm{a}(\mathrm{a})(1)$; (E) an assessment by the State educational agency of each school food authority's good faith effort to fulfill the proposals contained in the plan submitted under section $1758 \mathrm{a}(\mathrm{a})(\mathrm{l})$; and $(\mathrm{F})$ an enumeration of the measures the State educational agency intends to take to comply with section $1758 \mathrm{a}(\mathrm{b})(1)$.

(3) The State educational agency must make a good faith effort to fulfill the proposals contained in the plan submitted under section $1758 \mathrm{a}(\mathrm{b})(2)(\mathrm{A})-(\mathrm{C})$.

$\S 1758 \mathrm{~b}$. Receipt of full Federal funding or commodities conditioned on compliance with section 1758a; noncompliance; penalties.

(a) The Secretary shall condition the State educational agency's receipt of full Federal funding or commodities under this chapter and the Child Nutrition Act of $1966^{130}$ on compliance with section 1758a. The Sec-

130 The reference to the Child Nutrition Act of 1966, 42 U.S.C.A. $\$ \S 1772-87$ (Supp. 1976), amending 42 U.S.C. $\S \S 1771-85$ (1970), parallels the reference to that Act 
retary's finding of noncompliance with section 1758a shall result in a reduction of Federal funding to the State educational agency. The amount of such reduction shall be determined by the Secretary on the basis of the extent of the noncompliance and such other criteria as the Secretary may establish by regulation.

(b) Noncompliance with section 1758 a shall consist of (1) the failure of one or more participating school food authorities to file the plan required by section $1758 \mathrm{a}(\mathrm{a})(1) ;(2)$ the failure of a State educational agency to file the plan required by section $1758 \mathrm{a}(\mathrm{b})(2)$; (3) the failure of a State educational agency to comply with section $1758 \mathrm{a}(\mathrm{b})(1)$; (4) the failure of one or more participating school food authorities to make the good faith effort required by section $1758 \mathrm{a}(\mathrm{a})(2)$; or (5) the failure of a State educational agency to make the good faith effort required by section $1758 \mathrm{a}(\mathrm{b})(3)$.

\section{$\S 1758 c$. Secretary of Agriculture empowered to enact enforcement regulations.}

The Secretary is authorized (1) to enact regulations for the enforcement of section 1758a, and (2) to determine whether school food authorities and State educational agencies are making the good faith efforts required by sections $1758 \mathrm{a}(\mathrm{a})(2)$ and $1758 \mathrm{a}(\mathrm{b})(3)$, taking into account (a) the financial resources of each school food authority and State educational agency, (b) the rate of expansion of the program in the schools under the jurisdiction of each school food authority and State educational agency, and (c) such other criteria as the Secretary may establish by regulation.

The proposed statutory amendment is designed to fulfill the congressional goal of gradually providing a free or reduced price meal under the Act to every eligible child in the nation. ${ }^{131}$ It adopts the suggestion of the amicus curiae in Snodgrass ${ }^{\mathbf{1 3 2}}$ by requiring good faith attempts by state educational agencies and local school districts to bring every eligible child into the school lunch program. Section $1759 \mathrm{a}(\mathrm{e})(\mathrm{l})$ is abolished and new sections

in the present $\$ 1759 \mathrm{a}(\mathrm{e})(1)$ of the National School Lunch Act, 42 U.S.C.A.

$\S 1759 \mathrm{a}(\mathrm{e})(\mathrm{l})$ (Supp. 1976), amending 42 U.S.C. § 1759a(h)(1) (1970).

131 See note 124 supra.

${ }^{132}$ Text accompanying note 125 supra. 
$1758 \mathrm{a}$ through $1758 \mathrm{c}$ are created in its place. ${ }^{133}$ The requirement of the submission of a state plan is retained, and a correlative duty is imposed on the local school food authority to submit a plan describing how it proposes to expand coverage of the program to all schools and all eligible children under its jurisdiction.

Proposed section 1758 a begins with a statement of the amendment's policy: "For the purpose of ensuring the gradual extension of the coverage of the ... Act to all eligible children in the nation ...."This explicit statement is aimed at avoiding problems in judicial construction of the statute ${ }^{134}$ by clearly expressing a legislative intent to extend the program gradually to all eligible children in the nation.

The duties of both the state educational agency and the school food authority are set forth in proposed sections $1758 \mathrm{a}(\mathrm{a})(1)$ through $1758 \mathrm{a}(\mathrm{b})(3)$. Section $1758 \mathrm{a}(\mathrm{a})(1)$ of the proposed amendment requires all participating school food authorities to submit a plan to the appropriate state educational agency describing how they intend to include every school under their jurisdiction and every eligible child in their districts in the program. Section $1758 \mathrm{a}(\mathrm{b})(2)$ sets forth the requirement formerly contained in section $1759 \mathrm{a}(\mathrm{e})(1)^{135}$ that state educational agencies submit a plan describing how they intend to expand coverage of the program within their respective states. Moreover, the proposed amendment requires both participating school food authorities and state educational agencies to make good faith efforts to fulfill the objectives of their plans to expand coverage of the program. Additionally, section $1758 \mathrm{a}(\mathrm{b})(1) \mathrm{re}-$ quires state educational agencies to assist school food authorities in their good faith efforts to fulfill the objectives of their plans. Thus, the state retains its obligation to prod nonparticipating school districts into the program while the participating school districts are obligated to extend the program to nonparticpating

${ }^{133}$ The proposed amendment retains $\S 1759 a(e)(2)$, which requires each school participating in the school lunch program to file monthly reports with the state educational agency stating the average number of children who received free lunches and the average number of children who received reduced price lunches in the school in the preceding month, and $\S 1759 \mathrm{a}(\mathrm{e})(3)$, which requires each state educational agency to file monthly reports with the Secretary stating the average number of children in the state who received free lunches and the average number of children in the state who received reduced price lunches in the preceding month. These sections would be redesignated as $\$ \$ 1758 \mathrm{~d}$ and $1758 \mathrm{e}$ respectively.

${ }^{134}$ See, e.g., Richmond Welfare Rights Organization v. Snodgrass, 525 F.2d 197 (9th

Cir. 1975); Justice v. Board of Educ., 351 F. Supp. 1252 (S.D.N.Y. 1972).

${ }^{135}$ The text of $\S 1759 \mathrm{a}(\mathrm{e})(1)$ is reproduced in note 36 supra. 
schools within the school districts. The correlative duty imposed on participating school districts is aimed at increasing the efforts made to extend the program gradually to all schools and all eligible children in the nation-efforts limited presently to those of the state educational agencies. ${ }^{136}$

Proposed section $1758 \mathrm{~b}(\mathrm{a})$ provides that any noncompliance with section $1758 \mathrm{a}$, whether it is the noncompliance of one or more participating school food authorities within the state or the noncompliance of the state educational agency, ${ }^{137}$ will result in a reduction of federal funding to the state educational agency. The penalty for a school food authority's noncompliance is assessed against the state educational agency because a reduction in funding of a local school district may cause that district to terminate its participation in the program. ${ }^{138} \mathrm{~A}$ state, however, is more likely to have the financial resources to replace its lost funding and is less likely to withdraw from the program. ${ }^{139}$ Furthermore, a state educational agency's realization that a school food authority's failure to make a good faith effort to fulfill the objectives of its plan will result in a loss of funding to the state educational agency will encourage the agency to fulfill its obligation under proposed section $1758 \mathrm{a}(\mathrm{b})(\mathrm{l})$ to assist a school food authority in its efforts to comply with its good faith requirement.

The Secretary is given much discretion in determining whether a school food authority or state educational agency is making a good faith effort to meet the objectives of its respective plan. This discretion is intended to provide flexibility in the fulfillment of the goal of gradual expansion of the program. The proposed amendment, in accordance with the goal of gradual expansion, accommodates the difficulties that a state educational agency may have in extending the program to recalcitrant nonparticipating school districts and the fiscal constraints operating on the state educational agency and on the local school districts. No rigid formula for determining the good faith of a state educational agency or a school food authority is desirable.

Similarly, the standard for assessment of penalities does not lend itself to rigid definition. Presumably, noncompliance by one school food authority in a state where every other school food

${ }^{136}$ See text accompanying notes $124-27$ supra.

${ }^{137}$ Noncompliance is defined by proposed $\$ 1758 \mathrm{~b}(\mathrm{~b})$.

${ }^{138}$ See text accompanying notes 118-21 supra.

${ }^{139}$ The internal political pressures likely to be elicited by a state's attempt to withdraw from participation in the school lunch program almost certainly would prevent such a withdrawal. 
authority as well as the state educational agency are making good faith efforts to expand the program is not as serious as the failure of many school food authorities or the state educational agency to make a good faith effort in accordance with section 1758a. Vesting discretion in the Secretary to assess penalties for noncompliance provides the best means of making the punishment fit the gravity of the noncompliance.

The state educational agency is also required to make an assessment of each participating school food authority's good faith effort to fulfill the proposals contained in the plan it submits under proposed section $1758 \mathrm{a}(\mathrm{a})(1) .{ }^{\mathbf{1 4 0}}$ This requirement on the part of the state educational agency will aid the agency in carrying out another duty under the proposed amendment: the duty to assist school food authorities in making good faith efforts to comply with their plans submitted under section $1758 \mathrm{a}(\mathrm{a})(1) \cdot{ }^{141}$ If, upon review of a school food authority's activities, for example, the state educational agency determines that the school food authority is not making a good faith effort to comply with its plan, the state educational agency should assist the school food authority in making such an effort by, inter alia, informing it of what steps the agency believes are necessary for compliance with the good faith requirement and rendering administrative or financial aid to the school food authority. Such assistance will have the added virtue, from the state educational agency's point of view, of helping to avoid a finding by the Secretary that the school food authority has failed to comply with section $1758 \mathrm{a}(\mathrm{a})(2)$.

Moreover, this section of the amendment does not contemplate that the state educational agency is limited in the assistance it may provide to a school food authority by its assessment of the school food authority's good faith efforts. The state educational agency could assist school food authorities in making their good faith efforts by helping them devise the plans required under section $1758 \mathrm{a}(\mathrm{a})(1)$, reducing program costs by the bulk purchase of foods and the centralization of other administrative chores, or offering financial assistance even before the evaluation required under proposed section $1758 \mathrm{a}(\mathrm{b})(2)(\mathrm{E})$. Thus, in addition to retaining the state educational agency's obligation to extend the program to nonparticipating school districts, ${ }^{142}$ the proposed amendment makes clear that the state educational

\footnotetext{
${ }^{140}$ Proposed Amendment $\S 1758 \mathrm{a}(\mathrm{b})(2)(\mathrm{E})$.

141 Proposed Amendment $\$ 1758 \mathrm{a}(\mathrm{b})(1)$.

${ }^{142}$ See text accompanying note 123 supra.
} 
agency must still assist in the expansion of the program in participating school districts, notwithstanding the participating school district's new duty to make a good faith effort to expand the program.

By placing upon the state educational agency both the penalty for local noncompliance and the requirement of assisting local school districts in making good faith efforts to accomplish their section $1758 \mathrm{a}(\mathrm{a})(1)$ plans, the proposed amendment encourages states to render to participating school districts imaginative assistance to facilitate the goal of providing free or reduced price lunches to every eligible child in those districts.

\section{Conclusion}

The National School Lunch Act presently does not require a participating school district to provide free or reduced price lunches to all eligible children within the district. Because of partial coverage within a school district, children most in need have been denied the benefits of the school lunch program while less needy children have been assisted, schools with relatively few needy children have had lunch programs while schools having a large number of poor children have not, and children who were attending nonparticipating schools have been treated differently than their siblings who were attending participating schools. ${ }^{143}$ Congress sought to ensure the gradual extension of the coverage of the school lunch program to all eligible children in the nation by enacting section $1759 \mathrm{a}(\mathrm{e})(1)$, which requires, as a condition of the receipt of federal aid under the Act, state educational agencies to submit plans proposing the expansion of the program within the state. Section $1759 a(e)(1)$, however, does not place a correlative duty upon participating school districts to plan the expansion of the program within those districts. The proposed amendment to the Act better effectuates the congressional purpose underlying the enactment of section $1759 \mathrm{a}(\mathrm{e})(1)$ than that section presently does. The proposed amendment retains the state educational agency's obligation under section $1759 \mathrm{a}(\mathrm{e})(\mathrm{l})$ and, in addition, places upon participating school districts the duties of (1) planning the expansion of the program within the district and (2) making a good faith effort to fulfill the objectives of the plan, and requires the state educational agency to assist participating school districts in fulfilling their good faith obligation.

${ }^{143}$ E.g., Justice v. Board of Educ., 351 F. Supp. 1252, 1255 (S.D.N.Y. 1972). 